\title{
KARANTINA WILAYAH BERDASARKAN UNDANG-UNDANG NO 6 TAHUN 2018 TENTANG KEKARANTINAAN KESEHATAN
}

\author{
DESI SOMMALIAGUSTINA \\ Fakultas Hukum Universitas Muhammadiyah Riau \\ Email: desisommalia@umri.ac.id
}

Info Artikel:

Diterima: 10 Agustus 2021

| Disetujui: 10 Agustus 2021 | Dipublikasikan: 12 Agustus 2021

\begin{abstract}
Abstrak
Kemunculan pandemi virus corona di Wuhan, China, pada bulan Desember tahun lalu menjadi ancaman kematian global. Hal ini disebabkan kemampuan virus menyebar dengan cepat dan kemampuannya dalam menimbulkan dampak yang fatal bagi kesehatan. Kekhawatiran akibat dampak yang ditimbulkan virus corona, menyebabkan karantina kesehatan menjadi wacana yang harus segera dilakukan pemerintah Indonesia. Wacana ini berkembang karena termaktub dan tercantum jelas bahwa karantina kesehatan merupakan cara yang efektif memutus mata rantai penyebaran virus di saat terjadi kedaratan bencana seperti wabah virus corona hari ini yang dapat menimbulkan dampak dan kerugian besar bagi negara dan masyarakat Indonesia. Dalam Undang-Undang Nomor 6 Tahun 2018 Tentang Kekarantinaan Kesehatan dengan jelas menerangkan tentang adanya pembatasan mengenai masuk dan keluarnya individu ke suatu daerah yang telah dinyatakan sumber wabah, termasuk mengatur pula tentang adanya perintah untuk melakukan isolasi, karantina wilayah, vaksinasi dan lain sebagainya untuk menghentikan penyebaran wabah yang terjadi di Indonesia.
\end{abstract}

Kata Kunci: Virus Corona, Karantina, Undang-Undang

\section{REGIONAL QUARANTINE BASED ON LAW No. 6 OF 2018 CONCERNING HEALTH QUARANTINE}

\begin{abstract}
The appearance of the Corona virus pandemic in Wuhan, China, in December last year became a threat of global death. This is due to the rapidly spreading virus ability and its ability to inflict a fatal impact on health. Concerns due to the impact caused by Corona virus, cause health quarantine to be a discourse that the government should immediately do. This discourse develops because it is enlisted and clearly stated that health quarantine is an effective way to break the chain of virus spread in the event of catastrophic emergency such as Corona virus outbreak today that can cause substantial impact and loss for the country and Society of Indonesia. In Law No. 6 of 2018 concerning health's infidelity clearly describes the limitations on entrance and discharge of individuals to an area that has been declared the source of the plague, including also regulating the presence of orders for isolation, territorial quarantine, vaccination, etc. to stop the spread of the outbreak in Indonesia.
\end{abstract}

Keywords: Corona Virus, Quarantine, law 


\section{A. PENDAhuluan}

Munculnya wacana Kekarantinaan Kesehatan di Indonesia disebabkan adanya pandemi yang terjadi di dunia saat ini yaitu sebuah penyakit yang dinamai Coronavirus Disease atau virus corona Covid-19. Penyakit ini disebabkan oleh virus Systemic Acute Respiratory Syndrome (SARS) Coronavirus-2 (SARS-COV2). Virus yang terdeteksi pertama kali di Wuhan, China. Tepatnya di pasar seafood Hunan, yang mengakibatkan pada awal Desember tahun lalu ditemukan 50 kasus infeksi pernafasan (pneumonia). Dari Wuhan, virus ini kemudian menular ke banyak negara. Sehingga dengan masifnya penularan Covid-19 membuat dunia menjadi resah.

Virus ini diyakini dibawa oleh hewan-hewan yang dijual di pasar tradisional di Wuhan seperti kelelawar, anjing, ular dan lain sebagainya. Banyak peneliti percaya bahwa virus corona tersebut berpindah dari hewan yang ada di pasar ke manusia. Virus kemudian bermutasi sehingga kemudian menginfeksi orang lain. ${ }^{1}$ Namun lambat laun, ternyata banyak ditemukan kasus seseorang yang

\footnotetext{
1 Nabilla Ramadhian, "Lawan Corona, Akhirnya China Larang Masyarakatnya Konsumsi Hewa Liar," kompas.com, last modified 2020, https://amp.kompas.com/travel/read/2020/02/26/204 700227/lawan-corona-akhirnya-china-akan-larangmasyarakatnya-konsumsi-hewan-liar,diakses tanggal 17 April 2020.
}

tidak makan makanan dari Pasar Hunan di Wuhan namun terinfeksi virus ini. Saat itulah disimpulkan bahwa virus ini dapat menyebar melalui droplet (partikel), ketika manusia saling melakukan kontak dan berkomunikasi satu sama lain. Perlahanlahan, virus ini mengakibatkan 8.000 kematian dan ratusan ribu individu terinfeksi dalam 50 (lima puluh) hari pertama pasca ditetapkannya infeksi tersebut oleh pemerintah China. Akhirnya, dalam waktu yang tidak terlalu lama, infeksi virus ini menyebar ke lebih dari 100 (seratus) negara di dunia.

Dengan kata lain Covid-19 merupakan penyakit menular yang berpotensi menimbulkan kedaruratan kesehatan masyarakat. Oleh sebab itu, tindakan pencegahan terhadap jenis penyakit menular tersebut wajib dilakukan secepat mungkin. Beberapa tindakan telah dilakukan misalnya sejumlah negara telah melakukan langkah me-lockdown negaranya atau daerahnya untuk menekan penyebaran virus corona. Hal ini disebabkan wabah Covid-19 yang semakin mengganas dan menyebabkan banyaknya penduduk dunia terjangkit virus corona secara capat hingga menyebabkan kematian yang tidak sedikit. Penyebutan lockdown dalam Undang-Undang (UU) di Indonesia lebih dikenal dengan Karantina Wilayah 
atau Karantina Kesehatan. Adapun

Karantina kesehatan sendiri merupakan sebuah peraturan yang telah diatur dalam UU. Termaktub dan tercantum jelas bahwa karantina kesehatan merupakan cara yang efektif di saat terjadi kedaduratan bencana seperti wabah yang dapat menimbulkan dampak dan kerugian besar bagi negara. UU Nomor 6 Tahun 2018 Tentang Kekarantinaan Kesehatan dengan jelas menerangkan tentang adanya pembatasan mengenai masuk dan keluarnya individu ke suatu daerah yang telah dinyatakan sumber wabah, termasuk mengatur pula tentang adanya perintah untuk melakukan isolasi, karantina wilayah, vaksinasi dan lain sebagainya untuk menghentikan penyebaran wabah yang terjadi di Indonesia. $^{2}$

Beberapa negara yang sudah melakukan lockdown adalah Spanyol, Malaysia, Prancis, Italia, Denmark, Irlandia, Belanda, dan Belgia. Sementara di Indonesia langkah melakukan lockdown belum menjadi pilihan bagi pemerintah Indonesia meskipun terdapat desakan kepada pemerintah untuk melakukan lockdown sesegera mungkin, sebelum situasi menjadi bertambah buruk sebagaimana China, Itali, dan Korea

\footnotetext{
${ }^{2}$ Undang-Undang Nomor 6 Tahun 2018 Tentang Kekarantinaan Kesehatan.
}

Selatan. Desakan ini diakibatkan angka kematian di Indonesia akibat virus corona cukup tinggi. Berdasarkan data hingga 19 Maret 2020 yang ditayangkan pada video update 18 Maret 2020 oleh Kompas TV, menyebutkan terdapat 309 kasus positif virus corona di Indonesia. Sementara itu, sebanyak 25 orang meninggal dunia dan 15 orang dinyatakan sembuh. Dari data ini ternyata Indonesia menduduki peringkat ketiga resiko kematian akibat virus corona di dunia setelah China, Italia dan Korea Selatan yakni 8,3 persen. Sementara di China dari 81.000 lebih kasus infeksi virus corona tingkat kematian hanya 3,99 persen. Sementara di Italia tingkat kematian karena virus corona adalah 7,9 pesen. Adapun cara menghitung rasio tingkat kematian disebuah negara adalah dengan menghitung jumlah orang yang meninggal dunia kemudian dibagi dengan jumlah orang positif virus corona lalu dikali 100 persen. Lalu hasil itulah yangdisebut rasio tingkat kematian. $^{3}$

Melihat tingginya rasio kematian akibat virus corona di Indonesia, maka langkah antisipatif harus dilakukan sesegera mungkin. Langkah yang bisa diambil

\footnotetext{
3 Desi Sommaliagustina, "Lockdown Pariuk Nasi Akan Ambruk," The Columnist. id, last modified 2020, https://thecolumnist.id/artikel/-lockdownpariuk-nasi akan-ambruk-527, diakses pada tanggal 01 April 2020.
} 
misalnya melakukan lockdown atau social distancing. Untuk negara sebesar Indonesia dan ketidaksiapan Indonesia dari berbagai sisi maka lebih tepat yang dilakukan adalah semi lockdown atau social distancing. Hal ini disebabkan karena jika opsi lockdown diterapkan dalam kaitan pencegahan virus corona, maka pemerintah wajib mengunci seluruh akses masuk maupun keluar, dari suatu daerah maupun negara. Disamping itu jika lockdown diterapkan maka semua fasilitas publik harus ditutup. Seperti sekolah, pabrik, tempat umum, perkantoran, bahkan transportasi umum harus ditutup dan tidak diperkenankan beraktivitas. Dalam hal transportasi umum seperti pesawat jika lockdown dilakukan maka bisa dibayangkan ada begitu banyak penerbangan ditutup atau dibatalkan. Disamping itu, apabila langkah lockdown dipilih maka aktivitas warga juga akan dibatasi siang dan malam.

Hal ini dikarenakan lockdown merupakan kebijakan pemerintah untuk mengkarantina dan menutup suatu negara atau daerah. Sementara itu Direktur Riset Center of Reform on Economics (CORE) Indonesia Piter Abdullah mengatakan jika terjadi lockdown di Indonesia dampaknya akan jauh lebih besar dibandingkan negaranegara lain. Hal ini mengingat jumlah tenaga kerja Indonesia lebih banyak di sektor informal. ${ }^{4}$

Pernyataan ini tentu tidaklah mengada, mengingat banyaknya penduduk di Indonesia yang menggantungkan "pariuk nasi" di luar sektor formal misalnya para pedagang keliling, pemilik warung kelontong, pedagang di pasar tradisional dan lain sebagainya. Apabila lockdown dilakukan maka para pekerja di sektor informal tersebut akan kehilangan pendapatan dan "pariuk nasi" akan ambruk. Namun, apabila langkah lockdown terpaksa harus dilakukan maka pemerintah harus menyiapkan bantuan keuangan kepada masyarakat menengah ke bawah yang bekerja di sektor informal. Pemerintah harus menyiapkan bantuan tersebut agar masyarakat menengah ke bawah tidak mengalami kesulitan dalam hal keuangan. Sementara itu dalam hal penerapan social distance dilakukan bertujuan untuk mencegah orang sakit melakukan kontak dengan orang lain dalam jarak dekat, sehingga mengurangi penularan virus dari orang ke orang. Adapun hal terpenting untuk dilakukan dalam penerapan social distance adalah menjauhi segala bentuk perkumpulan, menjaga jarak dengan manusia, dan menghindari berbagai

${ }^{4}$ Ibid 
pertemuan yang melibatkan banyak orang.

Akan tetapi, meskipun Indonesia tidak melakukan langkah lockdown maka pemerintah juga perlu melakukan langkah lain sebagaimana yang dilakukan oleh negara lainnya yang juga tidak melakukan lockdown, misalnya negara Singapura dan Korea Selatan. Meskipun tidak melakukan lockdown pemerintah Singapura melakukan upaya nasional seperti mendeteksi kasus lebih awal sebelum virus corona di Singapura kian merebak dan tidak terkendali. Disamping itu, dengan alasan masyarakat Korea Selatan tidak siap untuk diisolasi atau dikarantina maka pemerintah Korea Selatan juga tidak melakukan lockdown. Tetapi pemerintah Korea Selatan melakukan tes massal kepada warga negaranya sehingga pemerintah Korea Selatan bisa melihat bagaimana tingkat persebaran virus corona di negaranya dan bisa dengan cepat untuk menanganinya. ${ }^{5}$

Dua upaya yang dilakukan oleh dua negara yang juga tidak melakukan lockdown tersebut bisa dicontoh oleh pemerintah Indonesia untuk mencegah rasio tingkat kematian akibat virus corona di Indonesia. Sehingga, di tengah kepanikan global akibat virus corona yang terjadi hari ini sudah saatnya para pemimpin memilik

\footnotetext{
${ }^{5}$ Ibid
}

pandangan yang sama dalam mengurai masalah ini. Karena masalah virus corona merupakan masalah serius dan tidak bisa disepelekan. Begitupun kita sebagai warga negara sudah saatnya saling bahu membahu mencari jalan keluar dari pendemik corona yang mematikan dan agar tidak pernah berputus pengharapan. Karena mengutip Yudi Latif, selalu ada sisi terang dari gelap.

Pemerintah Kota (Pemkot) Tegal memutuskan untuk menutup total akses ke wilayahnya atau disebut dengan Local Lockdown. Local Lockdown di Kota Tegal dilakukan selama empat bulan ke depan. Hal ini dilakukan untuk mencegah penyebaran virus corona atau Covid-19. Local Lockdown di Kota Tegal akan diterapkan pada 30 Maret 2020 dan berakhir 30 Juli 2020. Tegal menjadi kota pertama di Indonesia yang berani menerapkan langkah lockdown di Indonesia. Tentu saja, kebijakan Local Lockdown Pemkot Tegal ini akan berimbas ke aktivitas ekonomi kota bekas Karesidenan Pekalongan tersebut. Kebijakan ini dimaksudkan untuk menghentikan laju persebaran Covid-19 di wilayah Kota Tegal karena Kota Tegal telah ditetapkan masuk zona merah Covid$19 .^{6}$

\footnotetext{
${ }^{6}$ Desi Sommaliagustina, "Local Lockdown Solusi Perangi Pandemi?,'The Columnist. id, last modified
} 
Daerah di Indonesia yang masuk dalam zona merah tentu tidak hanya Tegal, mengingat penyebaran Covid-19 ini di Indonesia memang cukup cepat. Sejumlah informasi menyebutkan, per tanggal 28 Maret 2020, Covid-19 sudah merebak di 28 provinsi di Indonesia dengan jumlah pasien positif mencapai 1046 orang dan tingkat kematian 8,3\%. Melihat angka kematian yang cukup tinggi di Indonesia akibat Covid-19 tersebut, Indonesia sebenarnya punya waktu sekitar dua bulan sebelum Covid-19 yang sebelumnya mewabah di Wuhan itu datang ke Indonesia. Pada akhir Desember 2019, Organisasi Kesehatan Dunia (WHO) telah menyalakan alarm bahaya. Alarm bahaya dari WHO tersebut seharusnya disikapi dengan serius dan cepat tanggap oleh pemerintah Indonesia sejak awal. Namun yang sangat disayangkan respon awal pemerintah pada pandemi Covid-19 cukup membuat kita miris. Menantang Peneliti Harvard University, salah seorang Menteri berkelakar Covid-19 tidak masuk Indonesia karena pada gemar makan nasi kucing. ${ }^{7}$

Masalah lain yang muncul adalah terkait pihak yang berwenang dalam

2020, https://thecolumnist.id/artikel/local-lockdownsolusi perangi-pandemi-574, diakses pada tanggal 01 April 2020.

7 Ibid menetapkan kedaruratan kesehatan masyarakat, apakah pemerintah pusat ataupun pemerintah daerah. Walaupun Presiden telah menegaskan bahwa kebijakan lockdown tidak boleh diambil oleh pemerintah daerah, namun bisa saja kepala daerah mengambil kebijakan lockdown jika memang menurut kepala daerah itu wajib dilakukan. Jika memang pemerintah daerah mengambil kebijakan tersebut bisa jadi banyak pihak yang menganggap itu salah karena tidak sesuai dengan ketentuan undangundang, namun kalau respons pemerintah pusat lambat dan juga karena lemahnya regulasi maka tindakan tersebut dianggap hal yang lumrah dalam menghadapi ancaman darurat seperti Covid-19 ini. $^{8}$

Kemudian persoalan lainnya yang muncul yakni pemerintah dituntut untuk sesegera mungkin menangani ancaman nyata Covid-19. Jawaban sementara terkait dengan persoalan tersebut ternyata telah ada dalam Undang-Undang Nomor 6 Tahun 2018 tentang Kekarantinaan Kesehatan (selanjutnya dalam tulisan ini disebut UU Kekarantinaan Kesehatan). Dimana dalam undang-undang tersebut telah memuat banyak hal terkait dengan kekarantinaan kesehatan, pihak yang berwenang

\footnotetext{
${ }^{8}$ (Telaumbanua 2020)
} 
menetapkan kedaruratan kesehatan masyarakat, dan lain sebagainya. ${ }^{9}$

Tidaklah berlebihan apabila kemudian arus kritik terus datang kepada pemerintah. Diantara kritik itu mengatakan pemerintah terlambat mengantisipasi penyebaran Covid-19 di Indonesia. Hal ini dikarenakan korban akibat Covid-19 terus berjatuhan, rumah-rumah sakit kerepotan menghadapi pasien yang terus berdatangan, disamping pemerintah juga kelabakan untuk memasok alat kesehatan serta obat-obatan yang sudah langka di pasaran. Kondisi buruk lainnya adalah rumah-rumah sakit menghadapi kekurangan tenaga medis. Keadaan semakin buruk karena Alat Pelindung Diri (APD) untuk dokter terbatas, sehingga sejumlah dokter meninggal, dan yang terpapar terus bertambah. Berkaitan dengan permasalahan yang dihadapi tenaga kesehatan di lapangan juga sangat kompleks. Bukan saja berkaitan dengan masalah keterbatasan APD, para medis juga dihadapkan pada stigma negatif karena merawat pasien Covid-19. Misalnya peristiwa seorang perawat diusir dari tempat kosnya dan tidak diterima oleh tetangga karena menjalankan tugasnya. ${ }^{10}$

\footnotetext{
${ }^{9}$ Ibid

${ }^{10}$ Sommaliagustina, Loc.Cit
}

Peristiwa seperti ini tentu saja akan memberi dampak negatif pada tenaga kesehatan karena menurunkan motivasi dan akhirnya muncul masalah psikologis serta penurunan imunitas tenaga kesehatan itu sendiri. Seharusnya saat perhatian dunia terpusat pada masalah wabah virus corona atau Covid-19 yang sudah dinyatakan sebagai pandemi oleh Organisasi Kesehatan Dunia (WHO) dan merenggut banyak korban jiwa ini, maka kita sebagai bangsa yang berbudi luhur harus saling bergandengan tangan memutus mata rantai penyebaran Covid-19 yang menjadi masalah kita bersama.Di tengah kondisi Indonesia yang kian buruk, sudah saatnya kita menghentikan perbedaan pandangan termasuk menghentikan perdebatan setuju dan tidak setuju local lockdown atau karantina perbatasan dilakukuan karena wabah Covid-19.

Perdebatan itu dirasa tidak ada faedahnya mengingat virus corona sudah menyebar ke 28 provinsi di Indonesia. Melihat cepatnya penyebaran Covid-19 di Indonesia maka sangat diperlukan upaya strategis dan kongkrit untuk menanggulanginya. Diantara bentuk penanggulangan itu misalnya dalam hal pemenuhan ketersediaan tenaga medis dan 
peralatan medis, perlindungan yang baik terhadap tenaga kesehatan, perbaikan prosedur penanganan pasien, dan menjamin ketersediaan logistik dan keuangan bagi masyarakat menengah kebawah terutama ketika kebijakan Social Distencing dilakukan. Hal ini mengingat banyaknya masyarakat Indonesia yang bekerja di sektor informal dan berstrata sosial kelas menengah ke bawah yang akan mengalami dampak negatif apabila keadaan terus memburuk. ${ }^{11}$

Sebab sebagaimana yang kita ketahui, hari ini pemerintah mengeluarkan kebijakan Social Distancing untuk memutus mata rantai penyebaran Covid19. Namun, melihat kondisi hari ini yang jauh dari kata baik, dimana kecepatan penyebaran virus lebih tinggi dari kemampuan pemerintah mendeteksi mereka yang terpapar. Maka kebijakan Social Distencing dirasa masih belum cukup efektif. Tidak efektifnya kebijakan Social Distencing dapat dilihat ketika anjuran pemerintah untuk jaga jarak, kerja dari rumah, belajar dari rumah, ibadah dari rumah belum sepenuhnya ditaati. Hari ini kita masih bisa melihat orang-orang tetap bekerja di luar rumah. Pengendara ojek online masih tetap menjemput dan mengantarkan penumpangnya, pedagang buah masih berkeliling komplek menjajakan dagangannya, begitupun pedagang bakso, dan sejumlah pedagang lainnya. Hal demikian tentu saja berisiko dimana korban baru akibat terpapar wabah virus corona tidak bisa diprediksi. ${ }^{12}$

Apabila kebijakan Social Distancing yang dilakukan pemerintah hari ini tidak efektif maka langkah lain yang bisa dilakukan adalah local lockdown. Local lockdown sebagaimana yang disebutkan dalam Pasal 1 Angka (10) Undang Undang (UU) nomor 6 tahun 2018 disebut Karantina Wilayah. Karantina Wilayah adalah pembatasan penduduk dalam suatu wilayah termasuk wilayah pintu masuk beserta isinya yang diduga terinfeksi penyakit dan/atau terkontaminasi sedemikian rupa untuk mencegah kemungkinan penyebaran penyakit atau kontaminasi. Artinya melihat isi Pasal 1 Angka (10) UU nomor 6 tahun 2018 ini maka pemerintah bisa melakukan kebijakan lockdown di daerah yang terkena Covid-19 untuk mencegah penyebaran virus ke daerah lain secara lebih luas. Sedangkan untuk menjamin nasib masyarakat yang berpenghasilan rendah dan diperoleh secara harian maka local

\footnotetext{
${ }^{11}$ Ibid
} 
lockdown harus dibatasi jangka waktu berlakunya. Misalnya selama dua hingga tiga pekan atau hitungan bulan. Adapun kebutuhan masyarakat harus dijamin oleh pemerintah sebagaimana amanat undangundang seperti yang terkandung dalam Pasal 6 UU nomor 6 tahun 2018 dimana dinyatakan bahwa Pemerintah Pusat dan Pemerintah Daerah bertanggung jawab terhadap ketersediaan sumber daya yang diperlukan dalam penyelenggaraan Kekarantinaan Kesehatan.

Begitu pula pada Pasal 8 Undang Undang nomor 6 tahun 2018 menyebutkan bahwa setiap orang mempunyai hak mendapatkan pelayanan kesehatan dasar sesuai kebutuhan medis, kebutuhan pangan, dan kebutuhan kehidupan sehari-hari lainnya selama karantina. Dengan korban yang terus bertambah, maka karantina lokal merupakan salah satu solusi yang cukup baik untuk memutus mata rantai penyebaran Covid-19 yang cukup tinggi di Indonesia dengan catatan pemerintah harus menjalankan amanat UU termasuk dalam hal pemenuhan kebutuhan masayarakat yang sedang di karantina. Sehingga apabila kemudian local lockdown dilakukan dan kebutuhan masyarakat dipenuhi maka masyarakat tidak perlu gamang terhadap kebutuhan sehari-harinya selama masa karantina berlangsung.

\section{B. METODE PENELITIAN}

Penelitian ini disusun dengan jenis penelitian yuridis-normatif yaitu penelitian hukum yang dilakukan dengan cara meneliti bahan pustaka atau data sekunder saja disebut sebagai penelitian hukum normatif atau kepustakaan. Penelitian hukum normatif ini menggunakan pendekatan perundang-undangan.

\section{HASIL DAN PEMBAHASAN}

Presiden RI Joko Widodo untuk pertama kali mengumumkan bahwa dua orang di Indonesia positif terinfeksi virus Corona pada tanggal 2 April 2020 lalu di Istana Negara Jakarta. Menurut Jokowi, dua Warga Negara Indonesia (WNI) tersebut sempat kontak dengan warga negara Jepang yang datang ke Indonesia. Warga Jepang itu terdeteksi virus Corona setelah meninggalkan Indonesia dan tiba di Malaysia. ${ }^{13}$ Sejak Jokowi mengumumkan kabar yang ditunggu-tunggu itu hingga hari ini kasus positif virus Corona atau Covid19 di Indonesia terus bertambah. Pada tanggal 2 April 2020, pukul 12.00 WIB, jumlah pasien yang positif atas virus yang

\footnotetext{
13 Fathoni Ahmad, "Kasus Pertama, Dua Orang di Indonesia Positif Terinfeksi Virus Corona," Nuonline, last modified 2020, https://www.nu.or.id/post/read/117376/kasuspertama--dua-orang-di-indonesia-positif-terinfeksivirus-corona. diakses tanggal 28 Maret 2020.
} 
berasal dari Wuhan, China itu mencapai 1.790 orang $^{14}$ Dari jumlah itu, korban meninggal mencapai 170 jiwa, dan angka yang sembuh 112 orang. ${ }^{15}$

Tinggi tingkat kematian akibat virus corona di Indonesia membuat situasi tidak berjalan baik. Masyarakat khawatir terinfeksi virus corona. Situasi perekonomian juga tidak baik. Perdagangan lesu. Kebijakan Social Distancing yang dibuat oleh pemerintah agar orang bekerja dari rumah, belajar dari rumah dan beribadah dari rumah tentunya menimbulkan dampak ekonomi di masyarakat. Menteri Keuangan (Menkeu) Sri Mulyani Indrawati mengatakan penyebaran virus Corona yang massif di Indonesia membuat penurunan pada kegiatan ekonomi. Itu terjadi pada sektor lembaga keuangan di Indonesia seperti perbankan hingga konsumsi rumah tangga yang menurun. Di sektor konsumsi rumah tangga terjadi ancaman kehilangan pendapatan masyarakat karena tidak dapat bekerja untuk memenuhi kebutuhan hidup. Terutama rumah tangga miskin dan rentan

\footnotetext{
${ }^{14}$ https://m.caping.co.id/news/detailoppush?utm_sou rce $=6940758 \& \_$_p___detail \&barStyle__ $=1 \_1$. diakses tanggal 2 April 2020.

${ }^{15}$ CNN.Indonesia, "1790 Kasus, 170 Meninggal 112 sembuh,"https://m.cnnindonesia.com/nasional/20200 402142951-20-489609/update-corona-2-april-1790kasus-170-meninggaal-112-sembuh, diakses tanggal 2 April 2020.
}

serta sektor informal. ${ }^{16}$ Situasi seperti ini menimbulkan tanya dibenak banyak orang tentang sampai kapan akhir kondisi seperti yang terjadi hari ini. Apalagi korban jiwa terus berjatuhan. Kebijakan Social Distancing dirasa tidak cukup efektif menghentikan penyebaran virus.

Sehingga banyak yang menyuarakan agar kebijakan lockdown diambil oleh pemerintah pusat. Akan tetapi yang menjadi pertanyaan apa implikasi yuridis jika terjadi lockdown di Indonesia?

\section{Hak Rakyat Jika Terjadi Lockdown}

Saat ini virus Corona telah ditetapkan sebagai pandemi oleh organisasi kesehatan dunia (WHO). Beberapa negara telah menerapkan lockdown untuk mencegah penularan virus semakin luas. Defenisi lockdown merupakan tindakan darurat atau kondisi saat orang-orang untuk sementara waktu dicegah memasuki atau meninggalkan area atau bangunan yang telah ditentukan selama ancaman bahaya berlangsung. Beberapa negara yang telah menerapkan lockdown adalah Italia dan Denmark. Contoh dari kebijakan ini seperti meliburkan sekolah, dilarang bepergian,

\footnotetext{
16 Dwi Aditya Putra, "Skenario Terburuk Dampak Corona, Ekonomi Indonesia Tumbuh Negatif 0.4 $\%$," https://www.liputan6.com/bisnis/read/4216385/sken ario-terburuk-dampak-corona-ekonomi-indonesiatumbuh-negatif-04-persen.Liputan6.com, las modified 2020, diakses tanggal 2 April 2020.
} 
dan tidak boleh beraktivitas di area publik demi mencegah penyebaran virus. ${ }^{17}$ Dengan kata lain lockdown artinya negara mengunci akses masuk dan keluar masyarakatnya di dalam suatu daerah dengan tujuan mengantisipasi bertambah banyaknya jumlah korban jiwa akibat virus Corona.

\section{Implikasi Yuridis Apabila Indonesia Lockdown}

Berkaitan dengan keinginan sebagian masyarakat agar Indonesia lockdown sebagai upaya pencegahan penularan virus Corona, jika merujuk pada Undang Undang nomor 6 tahun 2018 tentang Kekarantinaan Kesehatan (UU Nomor 6 Tahun 2018) tidak menyebutkan istilah lockdown. Dalam UU Nomor 6 tahun 2018 yang disebutkan adalah Karantina Wilayah. Karantina Wilayah sebagaimana yang disebutkan dalam Pasal 1 Angka (10) adalah pembatasan penduduk dalam suatu wilayah termasuk wilayah pintu Masuk beserta isinya yang diduga terinfeksi penyakit dan/atau terkontaminasi sedemikian rupa untuk mencegah kemungkinan penyebaran penyakit atau kontaminasi.

\footnotetext{
${ }^{17}$ Harian Umum Haluan, "Arti Lockdown bedanya dengan Isolasi dan Karantina“" https://www.harianhaluan.com/news/detail/89356/ar ti-lockdown-bedanya-dengan-isolasi-dan-karantina, diakses tanggal 30 Maret 2020.
}

Akan tetapi berkaitan dengan penggunaan istilah lockdown apakah bisa disamakan dengan istilah Karantina Wilayah, ada pendapat yang beranggapan bahwa istilah lockdown merupakan istilah yang memiliki pengertian yang sama dengan istilah Karantina Wilayah. Tetapi ada pula yang berpendapat sebaliknya. Pendapat yang mengatakan lockdown merupakan kata lain dari Karantina atau Karantina Wilayah adalah Ubedilah Badrun. ${ }^{18}$ Ubedilah Badrun menyebutkan bahwa Lockdown itu istilah populernya, sementara Karantina itu istilah yang sesuai dengan UU Nomor 6 Tahun 2018. Sedangkan pendapat berbeda disampaikan oleh Dicky Budiman. Dicky Budiman menyebutkan istilah lockdown tidak dikenal dalam aturan kekarantinaan kesehatan di Indonesia. UU Nomor 6 Tahun 2018 memuat istilah karantina wilayah, defenisi serupa tapi tidak sama dengan lockdown. Karantina Wilayah dilakukan dalam ragka melakukan mitigasi faktor risiko di wilayah pada situasi Kedaruratan Kesehatan Masyarakat. Sehingga jika dipandang perlu akan

\footnotetext{
${ }^{18}$ Ubedillah Badrun, "Lockdown Covid-19: Dilema Ekonomi dan Nyawa Manusia,'Tempo.Co, last modified 2020, https://kolom.tempo.co/read/1323767/lockdowncovid-19-dilema-ekonomi-dan-nyawa manusia/full\&view=ok, diakses tanggal 27 Maret 2020 .
} 
dilakukan Karantina Rumah, Karantina

Wilayah, Karantina Rumah Sakit, atau

Pembatasan Sosial Berskala Besar oleh

Pejabat Karantina Kesehatan. ${ }^{19}$ Meskipun

terdapat perbedaan pendapat terkait makna

lockdown dan Karantina Wilah. Namun, dalam konteks ini yang dibicarakan adalah berkaitan dengan penutupan perbatasan wilayah Indonesia atau pembatasan sosial berskala besar dalam rangka penanggulangan penyebaran virus Corona di Indonesia.

Substansi penegakan hukum dalam aturan kekarantinaan memuat 2 (dua) hal yaitu pembinaan dan pengawasan. Pembinaan meliputi pengelolaan sumber daya, metode pendekatan penanggulangan, peningkatan kemampuan teknis SDM, serta penelitian dan pengembangan. Hal ini merupakan aspek penting yang perlu dibina dalam kekarantinaan agar sesuai dengan perkembangan yang ada saat ini

Pengawasan dilakukan agar tidak terjadi penyimpangan atau hal-hal yang dapat menghambat serta mempengaruhi pelaksanaan kekarantinaan. Pengaturan pengawasan kekarantinaan dimaksudkan agar dampak yang akan timbul akibat

19 Dicky Budiman, "Pilihan Strategi DKI Jakarta Tangani Covid-19," The Columnist.id, last modified 2020, https://thecolumnist.id/artikel/pilihan-strategidki-jakarta-tangani-covid19-573, diakses tanggal 1 April 2020. kejadian KLB/wabah dapat diminimalisir. Pembinaan terhadap petugas karantina diberikan untuk meningkatkan pemahaman tentang ketentuan di bidang karantian agar pelanggaran hukum di bidang kekarantinaan dapat dicegah. ${ }^{20}$

Adapun berkaitan dengan pembatasan sosial berskala besar dalam rangka penanggulangan penyebaran virus Corona di Indonesia diatur dalam UU Nomor 6 tahun 2018. Dalam UU ini menjelaskan sejumlah hal yang berkaitan dengan wabah penyakit seperti wabah virus Corona yang menjadi masalah global saat ini.

Hal ini sebagaimana diatur dalam Pasal 1 angka (1) UU Nomor 6 Tahun 2018 menyebutkan tentang kekarantinaan kesehatan yaitu upaya mencegah dan menangkal keluar atau masuknya penyakit dan/atau faktor risiko kesehatan masyarakat yang berpotensi menimbulkan kedaruratan kesehatan masyarakat. Berkaitan dengan kedaruratan kesehatan masyarakat dijelaskan pada Pasal 1 angka (2) UU Nomor 6 tahun 2018 yang menyebutkan bahwa kejadian kesehatan masyarakat yang bersifat luar biasa dengan ditandai penyebaran penyakit menular dan/atau kejadian yang disebabkan oleh radiasi nuklir, pencemaran biologi, kontaminasi

${ }^{20}$ (Setiawan 2020) 
kimia, bioterorisme, dan pangan yang menimbulkan bahaya kesehatan dan berpotensi menyebar lintas wilayah atau lintas negara.

Apabila melihat persebaran virus Corona yang demikian cepat diberbagai negara hingga sampai ke Indonesia dan mengakibatkan matinya orang dengan jumlah yang banyak dalam waktu dekat, serta perpindahan virus yang demikian massif, virus corona dapat dikategorikan sebagai penyebaran penyakit menular yang dapat memicu adanya kedaruratan kesehatan masyarakat. Dalam UU No. 6 tahun 2018 terdapat beberapa model Karantina. Dimana syarat utamanya adalah penentuan status darurat kesehatan nasional oleh Pemerintah Pusat, dalam hal ini adalah Presiden, yang diikuti dengan pembentukan satuan tugas untuk melakukan tindakan yang diperlukan untuk mengatasi sebuah wabah penyakit. Dalam hal ini pemerintah Indonesia telah menetapkan status bencana Covid-19 menjadi 91 hari hingga 29 Mei 2020. Hal ini berdasarkan surat keputusan Kepala Badan Penanggulangan Bencana (BNPB) Nomor 13 Tahun 2020 tentang Perpanjangan Status Keadaan Darurat
Bencana Wabah Penyakit Akibat Virus Corona di Indonesia dalam poin kedua. ${ }^{21}$ Apabila merujuk pada Undangundang No 6 tahun 2018 ini, ada beberapa macam jenis karantina yaitu Karantina Rumah, Karantina Wilayah dan Karantina Rumah Sakit. Dalam Pasal 50, 51 dan Pasal 52 dijelaskan tentang karantina rumah. Pasal 50 menyebutkan Karantina Rumah dilaksanakan pada situasi ditemukannya kasus Kedaruratan Kesehatan Masyarakat yang terjadi hanya di dalam satu rumah. Pasal ini dapatlah dipahami bahewa karantina rumah dilakukan hanya kalau kedaruratannya terjadi di satu rumah. Adapun karantina rumah meliputi orang, rumah dan alat angkut yang dipakai. Orang yang dikarantina tidak boleh keluar. Sebagaimana yang disebutkan pada Pasal 51 bahwa Penghuni rumah yang di karantina selain kasus, dilarang keluar rumah selama waktu yang telah ditetapkan oleh Pejabat Karantina Kesehatan. Adapun kebutuhan hidup mereka dijamin oleh negara. Hal ini sebagaimana yang disebutkan dalam Pasal 52 bahwa selama penyelenggaraan Karantina Rumah,

\footnotetext{
${ }^{21}$ Andrian Prataman Taher, "Pemerintah Perpanjang Status Darurat Bencana Covid-19 Hingga 29 Mei ," Tirto.id, last modified 2020, https://tirto.id/pemerintah-perpanjang-status-daruratbencana-covid-19-hingga-29-mei-eFJU, diakses tanggal 13 Maret 2020.
} 
kebutuhan hidup dasar bagi orang dan makanan hewan ternak yang berada dalam Karantina Rumah menjadi tanggung jawab Pemerintah Pusat.

Sementara itu pada Pasal 54 dijelaskan bahwa wilayah yang dikarantina diberi garis karantina dan dijaga terus menerus oleh pejabat Karantina Kesehatan dan Kepolisian Negara Republik Indonesia yang berada di luar wilayah karantina. Hal ini berarti bawa wilayah yang dikunci diberi tanda karantina, dijaga oleh aparat, anggota masyarakat tidak boleh keluar masuk wilayah yang dibatasi. Dan sekama karantin kebutuhan dasar mereka wajib dipenuhi oleh pemerintah. Sementara itu, dalam Pasal 56, 57 dan Pasal 58 dijelaskan tentang Karantina Rumah Sakit. Pasal 56 menyebutkan bahwa kegiatan Karantina Rumah Sakit merupakan bagian respons dari Kedaruratan Kesehatan Masyarakat. Sementara itu Pasal 57 menyebutkan bahwa Pejabat Karantina Kesehatan wajib memberikan penjelasan kepada orang yang berkunjung, orang yang bertugas di rumah sakit, dan pasien sebelum melaksanakan Karantina Rumah Sakit. Dimana rumah sakit yang dikarantina diberi garis karantina dan dijaga terus menerus oleh Pejabat Karantina Kesehatan, dan Kepolisian Negara Republik Indonesia yang berada di luar wilayah karantina.
Seluruh orang, barang, dan/atau hewan yang berada di rumah sakit yang dikarantina sebagaimana tidak boleh keluar dan masuk rumah sakit. Adapun Pasal 58 menyebutkan bahwa selama dalam tindakan Karantina Rumah Sakit, kebutuhan hidup dasar seluruh orang yang berada di rumah sakit menjadi tanggung jawab Pemerintah pusat dan/atau Pemerintah Daerah.

Dari sejumlah pasal dalam UU Nomor 6 tahun $2018^{22}$ tersebut sudah jelas menerangkan bahwa apabila terjadi sebuah wabah penyakit yang mematikan seperti wabah virus Corona yang terjadi hari ini maka pemerintah bisa mengambil tindakan dengan melakukan karantina wilayah dengan tujuan memberikan keamanan bagi masyarakat. Karena sebagaimana yang dikatakan Aristoteles bahwa tujuan negara adalah supaya warga negaranya dapat hidup baik dan bahagia. ${ }^{23}$ Sedangkan menurut pendapat Epicuros, tujuan negara adalah menyelenggarakan ketertiban dan keamanan serta ketentraman jiwa warga negara. $^{24}$ Adapun menurut John Locke, tujuan negara adalah untuk memelihara dan menjamin hak-hak asasi manusia. ${ }^{25}$

\footnotetext{
22 (Indonesia 2018)

23 Soehino, Ilmu Negara, (Liberty, Yogyakarta, 1999), hlm. 24.

${ }^{24}$ Ibid, hlm. 31.

${ }^{25}$ Ibid, hlm. 110.
} 
Menurut pendapat Immanuel Kant, tujuan negara adalah menjamin terlaksananya kepentingan umum di dalam keadaan hukum. ${ }^{26}$ Menurut Franz Magnis Suseno, tujuan negara adalah memajukan kepentingan- kepentingan masyarakat seoptimal mungkin berdasarkan solidaritas seluruh masyarakat dengan menjamin adanya kebebasan dari seluruh anggota masyarakat dan tidak mendapatkan kesewenang- wenangan dari penguasa. ${ }^{27}$ Sedangkan tujuan negara Kesatuan Republik Indonesia menurut UUD 1945 adalah membentuk suatu pemerintahan negara Indonesia yang melindungi segenap bangsa Indonesia dan seluruh tumpah darah Indonesia dan untuk memajukan kesejahteraan umum, mencerdaskan kehidupan bangsa dan ikut melaksanakan ketertiban dunia yang berdasarkan kemerdekaan, perdamaian abadi dan keadilan sosial. ${ }^{28}$

Menurut pendapat Miriam Budiardjo, tujuan negara (terlepas dari apapun ideologinya) meliputi mengusahakan kesejahteraan dan kemakmuran rakyatnya dan menegakkan keadilan melalui badan-

\footnotetext{
${ }^{26}$ Hassan Suryono, Ilmu Negara Suatu Pengantar ke Dalam Politik Hukum Kenegaraan, (UNS Press: Surakarta, 2008), hlm. 31.

${ }^{27}$ Ibid, hlm. 25.

28 Pembukaan Undang- Undang Dasar Negara Republik Indonesia Amandemen IV.
}

badan pengadilan. ${ }^{29}$ Saat ini yang dilakukan pemerintah adalah kebijakan pembatasan sosial alias social distancing. Pembatasan sosial diatur dalam Pasal 59 UU Nomor 6 Tahun 2018 yang menyebutkan bahwa Pembatasan Sosial Berskala Besar merupakan bagian dari respons Kedaruratan Kesehatan Masyarakat. Adapun tujuan Pembatasan Sosial Berskala Besar untuk mencegah meluasnya penyebaran penyakit Kedaruratan Kesehatan Masyarakat yang sedang terjadi antar orang di suatu wilayah tertentu. Pembatasan Sosial Berskala Besar paling sedikit meliputi peliburan sekolah dan tempat kerja, pembatasan kegiatan keagamaan dan atau pembatasan kegiatan di tempat atau fasilitas umum.

Namun meskipun pemerintah telah menghimbau agar-orang melakukan pembatasan sosial, tetapi hingga hari ini masih terdapat orang-orang yang tetap berpergian ke kantor, ke pasar, ke mall, ke dokter, ke rumah sakit, bahkan acara tertentu. Apabila melihat pola-pola penyebaran virus Corona yang telah terjadi, dimana orang-orang yang telah terinfeksi virus Corona bisa saja dengan mudah menyebarkan virus kepada orang

\footnotetext{
${ }^{29}$ Miriam Budiardjo, Dasar- Dasar Ilmu Politik, (Gramedia Pustaka Tama, Jakarta, 2005), hlm. 46.
} 
lain yang tidak terinfeksi, maka kebijakan social distancing yang telah diambil pemerintah tetapi tidak dipatuhi oleh masyarakat ini perlu dibuat kebijakan baru agar tidak membunuh lebih banyak lagi manusia. Hal ini dikarenakan apabila merujuk pada tujuan negara, maka sudah saatnya negara melalui pemerintah mengambil kebijakan yang dapat melindungi warga negaranya dengan melakukan upaya yang jelas dan terukur untuk memutus mata rantai penyebaran virus Corona. Hal ini bertujuan untuk menciptakan rasa aman bagi warga negaranya dari ancaman kematian.

\section{PENUTUP}

Covid-19 adalah masalah global yang menyebar dengan sangat cepak, dapat menginfeksi banyak orang dan menimbulkan banyak masalah di sejumlah negara termasuk Indonesia. Covid-19 adalah penyakit menular yang berasal dari negara China yang telah menular kebanyak orang di berbagai negara. Diperlukan upaya serius untuk menangkal penyakit tersebut dengan cara mencegah penularannya. Bahaya yang ditimbulkan oleh Covid-19 sangat besar maka sikap pemerintah dalam menangani penularan virus secara lebih luas perlu dilakukan. Karena apabila keadaan terus memburuk disebabakan penularan virus corona antar manusia tidak dapat ditekan maka dapat menyebabkan peningkatan jumlah orang yang tertular Covid-19 di Indonesia. Bedasarkan Undang-Undang Nomor 6 Tahun 2018 Tentang Kekarantinaan Kesehatan, dalam hal menahan serta menghentikan penyebaran virus maka pemerintah dapat melakukan tindakan karantina wilayah. Pada situasi krisis di tengah ancaman kematian global akibat pandemic maka pemerintah bisa mengambil sikap dengan tetap melakukan amanat sesuai UndangUndang demi melindungi segenap bangsa Indonesia. Karena ketidaktegasan pemerintah dalam mengambil kebijakan hanya akan menambah buruk keadaan. Apabila himbauan jaga jarak dan social distancing dirasa tidak efektif dalam menahan laju penyebaran virus corona di Indonesia maka penetapan karantina wilayah dapat menjadi solusi. Hal ini bertujuan untuk menghindari dampak yang sangat berbahaya di kemudian hari yang dapat mengancam nyawa masyarakat Indonesia. Karena ditengah situasi yang membahayakan seperti hari ini, penundaan penetapan karantina wilayah hanya dapat menyebabkan masalah baru seperti krisis ekonomi, peningkatan angka kejahatan, hingga kematian yang disebabkan oleh virus corona. 


\section{DAFTAR PUSTAKA}

Andrian Prataman Taher. 2020. Pemerintah Perpanjang Status Darurat Bencana Covid19 Hingga 29 Mei. Tirto.id. Last modified 2020.

https://tirto.id/pemerintah-perpanjangstatus-darurat-bencana-covid-19-hingga-29mei-eFJU

CNN.Indonesia. 2020. "1790 Kasus, 170 Meninggal 112 sembuh." https://m.cnnindonesia.com/nasional/20200 402142951-20-489609/update-corona-2april-1790-kasus-170-meninggaal-112sembuh.

Dalinama Telaumbanua. 2020. "Urgensi Pembentukan Aturan Terkait Pencegahan Covid-19 di Indonesia." Qalamuna - Jurnal Pendidikan, Sosial, dan Agama 12 (1).

Desi Sommaliagustina. 2020. Lockdown Pariuk Nasi Akan Ambruk. The Columnist.id. Last modified 2020.

https://thecolumnist.id/artikel/-lockdownpariuk-nasi-akan-ambruk-527.

Desi Sommaliagustina. 2020. Local Lockdown Solusi Perangi Pandemi?. The Columnist.id. Last modified 2020, https://thecolumnist.id/artikel/local lockdown-solusi-perangi-pandemi-574.

Dicky Budiman. 2020. Pilihan Strategi DKI Jakarta Tangani Covid-19. The Columnist.id. Last modified 2020.

Https://thecolumnist.id/artikel/pilihanstrategi-dki-jakarta-tangani-covid19-573.

Dwi Aditya Putra. 2020. "Skenario Terburuk Dampak Corona, Ekonomi Indonesia Tumbuh Negatif $0.4 \%$,". Liputan6.com. Last modified 2020. Https://www.liputan6.com/bisnis/read/4216 385/skenario-terburuk-dampak-coronaekonomi-indonesia-tumbuh-negatif-04persen.

Fathoni Ahmad. 2020. "Kasus Pertama, Dua Orang di Indonesia Positif Terinfeksi Virus Corona,". NUonline. Last modified 2020, Https://www.nu.or.id/post/read/117376/ka us-pertama--dua-orang-di-indonesia-positif terinfeksi-virus-corona.

Harian Umum Haluan. 2020. "Arti Lockdown bedanya dengan Isolasi dan Karantina."
Https://www.harianhaluan.com/news/detail/ 89356/arti-lockdown-bedanya-denganisolasi-dan-karantina.

Hassan Suryono. 2008. Ilmu Negara Suatu Pengantar ke Dalam Politik Hukum Kenegaraan. UNS Press: Surakarta.

Https://m.caping.co.id/news/detailoppush?utm source $=6940758 \& \_$_pf__ detail \&barStyl e_ $=1 \_1$.

Indonesia. 2018. Undang-Undang Republik Indonesia Nomor 6 Tahun 2018 Tentang Kekarantinaan Kesehatan.

Miriam Budiardjo. 2005. Dasar- Dasar Ilmu Politik. Gramedia Pustaka Tama, Jakarta.

Nabilla Ramadhian. 2020. "Lawan Corona, Akhirnya China Larang Masyarakatnya Konsumsi Hewa Liar," kompas.com, last modified2020,

https://amp.kompas.com/travel/read/2020/0 2/26/204700227/lawan-corona-akhirnyachina-akan-larang-masyarakatnyakonsumsi-hewan-liar.

Soehino. 2000. Ilmu Negara. Liberty: Yogyakarta.

Setiawan, Y.I.S..2020."Penetapan Karantina Wilayah Menurut Pandangan Legal Positivisme Dalam Rangka Pencegahan dan Pemberantasan Pandemi Coronavirus Disease (Covid)-19." OSF Preprint, 2020.

Ubedillah Badrun. 2020. "Lockdown Covid-19: Dilema Ekonomi dan Nyawa Manusia," Tempo.Co. Last modified 2020. Https://kolom.tempo.co/read/1323767/lock down-covid-19-dilema-ekonomi-dannyawa manusia/full\&view $=$ ok.

Undang-Undang Dasar 1945. 